\title{
Molecular Imaging for Thyrotoxicosis and Thyroid Nodules
}

\author{
Luca Giovanella ${ }^{1,2}$, Anca Avram ${ }^{3}$, and Jerome Clerc ${ }^{4}$ \\ ${ }^{I}$ Clinic for Nuclear Medicine and Competence Center for Thyroid Diseases, Imaging Institute of Southern Switzerland, Ente \\ Ospedaliero Cantonale, Bellinzona, Switzerland; ${ }^{2}$ Clinic for Nuclear Medicine, University Hospital and University of Zurich, Zurich, \\ Switzerland; ${ }^{3}$ Division of Nuclear Medicine, Department of Radiology, University of Michigan, Ann Arbor, Michigan; and ${ }^{4}$ Department \\ of Nuclear Medicine, Cochin Hospital, Assistance Publique Hôpitaux de Paris, DMU Imagina, University of Paris, Paris, France
}

\begin{abstract}
After exclusion of exogenous iodine overload, radioiodine uptake (RAIU) testing with ${ }^{123}$ I or ${ }^{131}$ I enables the accurate evaluation and quantification of iodine uptake and kinetics within thyroid cells. In addition, scintigraphic evaluation with ${ }^{123}$ I or ${ }^{99 m} \mathrm{Tc}$-pertechnetate $\left({ }^{99 m} \mathrm{Tc04}-\right)$ provides the topographic distribution of thyroid cell activity and allows the detection and localization of ectopic thyroid tissue. Destructive thyrotoxicosis is characterized by abolished or reduced uptake whereas productive thyrotoxicosis (i.e., hyperthyroidism "sensu strictu") is characterized by high RAIU with scintigraphically diffuse (i.e., Graves disease and diffuse thyroid autonomy) or focal (i.e., autonomously functioning thyroid nodules [AFTN]) overactivity. Accordingly, RAIU or thyroid scintigraphy are widely used to differentiate different causes of thyrotoxicosis. In addition, several radiopharmaceuticals are also available to help in differentiating benign from malignant thyroid nodules and inform clinical decision making. In fact, AFTNs can be safely excluded from fine-needle aspiration biopsy while either ${ }^{99 \mathrm{~m}} \mathrm{Tc}$-methoxyisobutylisonitrile (MIBI) and ${ }^{18} \mathrm{~F}-\mathrm{FDG}$ may complement the work-up of cytologically indeterminate cold nodules and contribute to reducing the need for diagnostic lobectomies/thyroidectomies. Finally, RAIU studies are also useful for calculating the administered therapeutic activity of ${ }^{131}$ I to treat hyperthyroidism and euthyroid multinodular goiter. All considered, thyroid molecular imaging allows us to characterize molecular/functional aspects of different thyroid diseases, even before clinical symptoms become manifest and remains integral to properly managing such conditions. Our present paper summarizes basic concepts, clinical applications, and potential developments of thyroid molecular imaging in patients affected by thyrotoxicosis and thyroid nodules.
\end{abstract}

Key Words: hyperthyroidism; molecular imaging; thyroid nodules; thyroid functional autonomy

J Nucl Med 2021; 62:20S-25S

DOI: 10.2967/jnumed.120.246017

$\mathbf{R}$ adioiodine uptake (RAIU) testing and thyroid scintigraphy (TS) remained the only methods to evaluate both functional and morphologic aspects of the thyroid gland and its diseases for decades. Subsequently, with the development of immunometric assays, multiparametric thyroid ultrasound (MPUS), and fine-needle aspiration (FNA), the use of TS and RAIU tests has decreased. However, TS remains the only method able to differentiate "productive" from "destructive" thyrotoxicosis and detect thyroid

\footnotetext{
Received Jul. 1, 2020; revision accepted Sep. 21, 2020.

For correspondence or reprints, contact Luca Giovanella (luca.giovanella@ eoc.ch).

COPYRIGHT (C 2021 by the Society of Nuclear Medicine and Molecular Imaging.
}

functional autonomy (TFA) $(1,2)$. Although the spatial resolution of TS is approximately 5-7 mm compared with $1 \mathrm{~mm}$ for MPUS, smaller sites of hyperfunctioning thyroid tissue may be detectable provided the target-to-background count rate ratio is adequately high (i.e., $>2.5$ times) as it is expected in thyroid autonomy. Such foci are rendered in the image larger than actual size (i.e., partialvolume effect) and this should be considered; however, functional information remain clinically relevant. Additionally, different tracers able to evaluate the proliferation rate of cold thyroid nodules are available to support the management of cytologically indeterminate cold nodules and limit unnecessary lobectomies/thyroidectomies $(3,4)$. The aim of our paper is to summarize molecular imaging methods available for thyroid evaluation and provide practical suggestions for their optimized use in clinical practice.

\section{THYROID MOLECULAR IMAGING: BASIC CONCEPTS}

Normal thyroid follicular cells trap stable iodine by the sodium (i.e., natrium) iodide symporter, a laterobasal transmembrane glycoprotein. Then, iodine is transported at the apical membrane into the follicular lumen and incorporated into selected tyrosyl residues of thyroglobulin to form thyroxine (T4) and triiodothyronine (T3) $(5,6)$. Under physiologic conditions the thyroid-stimulating-hormone (TSH), leading in first approximation an inverse log-linear relationship TSH/FT4 (7) and a positive linear relationship TSH/ RAIU, respectively (8), mainly regulates the process. The thyroid gland mainly produces $\mathrm{T} 4$, which accounts for $85 \%-90 \%$ of thyroid hormones, whereas the bioactive T3 largely derives from peripheral conversion of T4 under the action of liver deiodinases. More than $99 \%$ of T4 and T3 molecules are tightly bound to the carrier proteins, thyroid-binding globulin, transthyretin, and albumin, and only a small percentage circulates as free hormones $(9,10)$.

\section{Tracing Thyroid Function}

${ }^{123} \mathrm{I}$ is an ideal thyroid radiopharmaceutical because of its low radiation burden and optimal imaging quality compared with ${ }^{131} \mathrm{I}$, which is strongly discouraged for routine diagnostic use because of its much higher radiation burden to the thyroid. ${ }^{124} \mathrm{I}$ is a positron-emitting isotope that allows high-quality imaging of the thyroid: its use, however, is restricted to clinical trials involving individuals with differentiated thyroid cancer (1). Different tracers, such as ${ }^{99 \mathrm{~m}} \mathrm{Tc}$-pertechnetate $\left({ }^{99 \mathrm{~m}} \mathrm{Tc} 04-\right)$ and ${ }^{18} \mathrm{~F}$-tetrafluoroborate, are also trapped by the sodium iodide symporter, but wash out completely from thyroid cells in about $30 \mathrm{~min}$ and are not organified. In most cases, ${ }^{99 \mathrm{~m}} \mathrm{Tc} 04$ - imaging provides the clinical information needed $(1,11)$ and, being inexpensive and readily available from on-site generators, is widely used in clinical practice. On the other hand, ${ }^{123}$ I allows a precise quantification of both iodine 
TABLE 1

Thyrotoxicosis: Etiology, Pathophysiology, and Relevant Points for Differential Diagnosis

\begin{tabular}{|c|c|c|c|c|c|}
\hline Disease & Etiology & Pathophysiology & Laboratory & Thyroid scan and RAIU & MPUS \\
\hline GD & Autoimmune & TSH-R stimulation & $\begin{array}{l}\text { TSH, fT4/fT3; TRAb+ } \\
\quad 95 \%-99 \% ; \text { TPOAb }+ \\
\quad \sim 60 \%\end{array}$ & Uptake (diffuse) & $\begin{array}{l}\text { Hypoechoic pattern; } \\
\text { Vascular flow } \\
\text { (diffuse) }\end{array}$ \\
\hline \multirow[t]{3}{*}{ GD variants } & Autoimmune & Mixed GD/AITD & $\begin{array}{l}\text { TSH, fT4/fT3; TRAb+ } \\
\text { 95\%-99\%; TPOAb+ } \\
\quad \sim 80 \%\end{array}$ & Uptake (heterogeneous) & $\begin{array}{l}\text { Hypoechoic pattern; } \\
\text { Vascular flow } \\
\text { (diffuse) }\end{array}$ \\
\hline & Autoimmune & $\begin{array}{l}\text { GD+hypofunctioning } \\
\text { nodule(s) }\end{array}$ & $\begin{array}{l}\text { TSH, fT4/fT3; TRAb + } \\
\text { 95\%-99\%; TPOAb+ } \\
\quad \sim 60 \%\end{array}$ & $\begin{array}{l}\text { Uptake (diffuse) with cold } \\
\text { nodule(s) }\end{array}$ & $\begin{array}{l}\text { Hypoechoic } \\
\text { diffuse variable } \\
\text { for nodules }\end{array}$ \\
\hline & Autoimmune & $\begin{array}{l}\text { GD+hyperfunctioning } \\
\text { nodule }\end{array}$ & $\begin{array}{l}\text { TSH, fT4/fT3; TRAb+ } \\
\text { 95\%-99\%; TPOAb+ } \\
\quad \sim 60 \%\end{array}$ & $\begin{array}{l}\text { Marine-Lenhardt } \\
\text { syndrome }\end{array}$ & Aspecific pattern \\
\hline TFA & Somatic mutations & $\begin{array}{l}\text { Overactive TSH-R; } \\
\text { overactive Gs } \alpha- \\
\text { subunit }\end{array}$ & $\begin{array}{l}\text { TSH, fT4/fT3; no specific } \\
\text { biomarkers }\end{array}$ & $\begin{array}{l}\text { TSH-independent thyroid } \\
\text { uptake }\end{array}$ & Aspecific pattern \\
\hline \multirow[t]{3}{*}{ TFA variants } & Somatic mutations & Unifocal autonomy & $\begin{array}{l}\text { TSH, fT4/fT3; no specific } \\
\text { biomarkers }\end{array}$ & $\begin{array}{l}\text { TSH-independent unifocal } \\
\text { uptake }\end{array}$ & Aspecific pattern \\
\hline & Somatic mutations & Multifocal autonomy & $\begin{array}{l}\mathrm{TSH}, \mathrm{fT} 4 / \mathrm{fT} 3 \text {; no specific } \\
\text { biomarkers }\end{array}$ & $\begin{array}{l}\text { TSH-independent } \\
\text { multifocal uptakes }\end{array}$ & Aspecific pattern \\
\hline & Somatic mutations & $\begin{array}{l}\text { Disseminated } \\
\text { autonomy }\end{array}$ & $\begin{array}{l}\mathrm{TSH}, \mathrm{fT} 4 / \mathrm{fT} 3 \text {; no specific } \\
\text { biomarkers }\end{array}$ & $\begin{array}{l}\text { TSH-independent diffuse } \\
\text { uptake }\end{array}$ & Aspecific pattern \\
\hline $\begin{array}{l}\text { Subacute } \\
\text { thyroiditis }\end{array}$ & Viral & $\begin{array}{l}\text { Inflammatory } \\
\text { destruction }\end{array}$ & $\begin{array}{c}\text { TSH, fT4/fT3; ESR/CRP; } \\
\text { TPOAb + infrequent }\end{array}$ & $\begin{array}{l}\text { Absent to uptake (early } \\
\text { phase) }\end{array}$ & $\begin{array}{l}\text { Hypoechoic; irregular } \\
\text { vascular flow }\end{array}$ \\
\hline $\begin{array}{l}\text { Painless } \\
\text { thyroiditis }\end{array}$ & Autoimmune & $\begin{array}{l}\text { Transient immuno- } \\
\text { mediated cytolysis }\end{array}$ & $\begin{array}{l}\text { TSH, fT4/fT3; TPOAb+ } \\
\text { 95\%-99\%; normal } \\
\text { ESR/CRP }\end{array}$ & $\begin{array}{l}\text { Absent to uptake (early } \\
\text { phase) }\end{array}$ & $\begin{array}{l}\text { Hypoechoic; normal } \\
\text { to vascular flow }\end{array}$ \\
\hline \multirow[t]{4}{*}{ Drug induced } & lodine overload & $\begin{array}{c}\text { AlH type 1: pathologic } \\
\text { escape from Wolff- } \\
\text { Chaickoff effect }\end{array}$ & TSH, fT4/fT3; ioduria & $\begin{array}{l}\text { Uptake with visible } \\
\text { contrast }\end{array}$ & Aspecific pattern \\
\hline & lodine overload & $\begin{array}{l}\text { AlH type } 2 \text { : iodine- } \\
\text { induced destructive } \\
\text { thyroiditis }\end{array}$ & TSH, fT4/fT3; ioduria & Absent uptake & $\begin{array}{l}\text { Hypoechoic; irregular } \\
\text { vascular flow }\end{array}$ \\
\hline & TKI, ICPI & Destructive thyroiditis & $\begin{array}{l}\text { TSH, fT4/fT3; TPOAb+ } \\
\text { variable }\end{array}$ & Absent to uptake & Aspecific pattern \\
\hline & $\begin{array}{l}\text { Factitious } \\
\text { thyrotoxicosis }\end{array}$ & T4, T3, TH analogs & $\begin{array}{l}\text { TSH, fT4/fT3; } \\
\text { thyroglobulin }\end{array}$ & Absent to uptake & $\begin{array}{l}\text { Normal to vascular } \\
\text { flow }\end{array}$ \\
\hline \multirow[t]{3}{*}{ Tumors } & Struma ovarii & $\begin{array}{l}\text { Ovarian } \mathrm{TH} \\
\text { biosynthesis }\end{array}$ & $\begin{array}{l}\text { TSH, fT4/fT3; } \\
\text { thyroglobulin }\end{array}$ & Suppressed to uptake & $\begin{array}{r}\text { Normal thyroid pelvic } \\
\text { US: ovarian tumor }\end{array}$ \\
\hline & Thyroid cancer & $\begin{array}{l}\text { Functioning } \\
\text { metastasis }\end{array}$ & $\begin{array}{l}\text { TSH, fT4/fT3; } \\
\text { thyroglobulin }\end{array}$ & $\begin{array}{l}\text { Consider }{ }^{131} \text { I-WBS } \\
\quad \text { (thyroid suppressed) }\end{array}$ & $\begin{array}{l}\text { Suspicious lymph } \\
\text { nodes and thyroid } \\
\text { nodules }\end{array}$ \\
\hline & Germinal tumors & $\beta \mathrm{HCG}$ overproduction & TSH, fT4/fT3; $\beta \mathrm{HCG}$ & Normal to diffuse uptake & $\begin{array}{l}\text { Normal to vascular } \\
\text { flow }\end{array}$ \\
\hline \multirow[t]{2}{*}{ Central } & Pituitary resistance & THR mutation (TR $\beta)$ & $\begin{array}{l}\text { Normal to TSH; normal to } \\
\text { fT4/fT3 }\end{array}$ & Normal to diffuse uptake & $\begin{array}{l}\text { Normal to vascular } \\
\text { flow }\end{array}$ \\
\hline & Pituitary adenoma & TSH-secreting tumor & $\begin{array}{l}\text { Normal to TSH; normal to } \\
\text { fT4/fT3; TSH } \alpha \text {-subunit }\end{array}$ & Normal to diffuse uptake & $\begin{array}{l}\text { Normal to vascular } \\
\text { flow }\end{array}$ \\
\hline
\end{tabular}

$\mathrm{AlH}=$ amiodarone-induced hyperthyroidism; AITD = autoimmune thyroid diseases; CRP = C-reactive protein; ESR = erythrocyte sedimentation rate; $\mathrm{fT} 3$ = free triiodothyronine; $\mathrm{fT} 4$ = free thyroxine; GD = Graves disease; HCG = human chorionic gonadotropin; ICPI = immune checkpoint inhibitor; TFA = thyroid functional autonomy; TH = thyroid hormone; THR = thyroid hormone receptor; TKI = thyrosine kinase inhibitors; TPOAb = thyroperoxidase antibody; TRAb $=$ TSH-receptor antibody; TR $\beta=$ thyroid receptor $\beta$; TSH $=$ thyroid stimulating hormone; TSH-R = TSH-receptor; T4 = thyroxine; T3 = liothyronine; US = ultrasound; WBS = whole-body scintigraphy. 


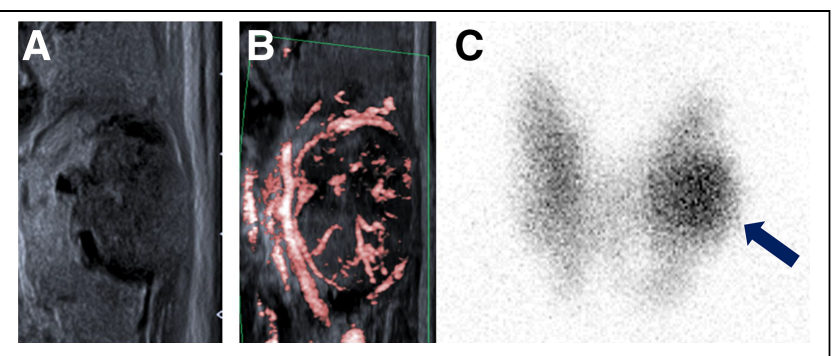

FIGURE 1. Sonographically suspicious left thyroid nodule in patient with normal TSH level (i.e., $1.24 \mathrm{mUI} / \mathrm{L})$. FNA biopsy demonstrated follicular neoplasm (Bethesda IV cytology). MPUS shows slightly irregular hypoechoic nodule (A) with increased vascularization (B). ${ }^{123}$ I TS depicted AFTN (C) excluding malignancy.

trapping and organification and supports individual dosimetric therapy planning $(3,11,12)$.

\section{Tracing Thyroid Growth and Proliferation}

${ }^{99 \mathrm{~m}} \mathrm{Tc}-\mathrm{MIBI}$ is a lipophilic cation that crosses the cell membrane and penetrates reversibly into the cytoplasm and then irreversibly into the mitochondria (13). Transmembrane glucose transporters and hexokinases mediate the cellular uptake and retention of ${ }^{18}$ F-FDG, respectively. Notably, higher ${ }^{99 \mathrm{~m}} \mathrm{Tc}-\mathrm{MIBI}$ and ${ }^{18} \mathrm{~F}-\mathrm{FDG}$ uptake are expected in thyroid cancers due to the higher electrical gradient of mitochondrial membrane and insulin-independent glucose consumption of cancer cells compared with either normal cells and those forming benign thyroid nodules $(13,14)$.

\section{Diagnostic Procedures}

Extensive information on radiopharmaceutical activities, instrumentations, imaging protocols, interpretation criteria, and reporting can be found in recently published joint EANM practice guideline/SNMMI procedure standard for RAIU and TS (1).

\section{THYROTOXICOSIS}

Thyrotoxicosis refers to the clinical syndrome of excess circulating thyroid hormones, irrespective of the source, whereas hyperthyroidism is characterized by increased thyroid hormone synthesis and secretion from the thyroid gland (15). The clinical presentation of thyrotoxicosis ranges from asymptomatic to thyroid storm, depending by its intensity and duration. Accordingly, besides clinical examination serum TSH measurement is integral to confirm $(\mathrm{TSH}<0.1 \mathrm{mUI} / \mathrm{L})$ or exclude $(\mathrm{TSH}>0.4 \mathrm{mUI} / \mathrm{L})$ hyperthyroidism, with values between 0.1 and $0.4 \mathrm{mUI} / \mathrm{L}$ considered as a gray area requiring serial testing for surveillance. Serum concentrations of free T4 and free T3 differentiate subclinical from overt hyperthyroidism and assess the severity of the latter (16-18). The most common cause of hyperthyroidism is Graves disease (GD), followed by TFA. The latter may present as unifocal or multifocal autonomously functioning thyroid nodules (AFTNs) or disseminated gland overactivity $(19,20)$. TFA is rare $(<10 \%)$ in countries with adequate iodine supply but its prevalence significantly increases (up to $20 \%$ and more) in countries with current or previous iodine deficiency (21). Other causes of thyrotoxicosis include destructive thyroiditis, iodine-induced and drug-induced thyroid dysfunction, and factitious ingestion of excess thyroid hormones. Then, an accurate differential diagnosis is required to properly treat patients $(22,23)$. Depending on the available resources, TSH receptor antibody (TRAb) measurement (24), TS or RAIU $(25,26)$, and MPUS with color flow Doppler evaluation can be used (27). A recent study on 124 consecutive patients with newly diagnosed and untreated hyperthyroidism compared 2 TRAb assays, TS and MPUS, respectively (28). Thyroid MPUS was less accurate than both TRAb and TS, with the exception of a vascular thyroid inferno pattern, which provides a high positive predictive value (PPV) for GD. TS was the most reliable tool for differential diagnosis, and easily delineated different GD and TFA variants, including Marine-Lenhardt syndrome and compensated autonomy $(2,19,29-31)$. However, depending on locally available facilities, TRAb assays can be adopted as a first-line diagnostic option limiting the use of TS to TRAb-negative patients. Notably, exogenous iodine overload should be always investigated as it may lead to a sustained increase in hormone synthesis and, eventually, thyrotoxicosis with inhibition of TSH and decreased uptake due to an expanded iodine pool mimicking the early phase of destructive thyroiditis on TS. Finally, conventional TS is unsuitable to differentiate type 1 from type 2 amiodarone-induced hyperthyroidism $(\mathrm{AIH})$ because iodine trapping and organification are reduced by exogenous iodine overload. Using ${ }^{99 \mathrm{~m}} \mathrm{Tc}-\mathrm{MIBI}$ TS, which demonstrates preserved MIBI uptake in type I AIH and decreased MIBI uptake in type $2 \mathrm{AIH}$, may be useful in such cases for determining clinical management $(32,33)$. Etiology, pathophysiology, and differential diagnosis of thyrotoxicosis are summarized in Table 1.

\section{THYROID NODULES}

Thyroid nodules are commonly detected in clinical practice, and thus it is necessary to decide which ones carry a significant risk of malignancy and require further workup with FNA (34). MPUS provides an accurate assessment of morphologic features, which have been recently used to produce a 


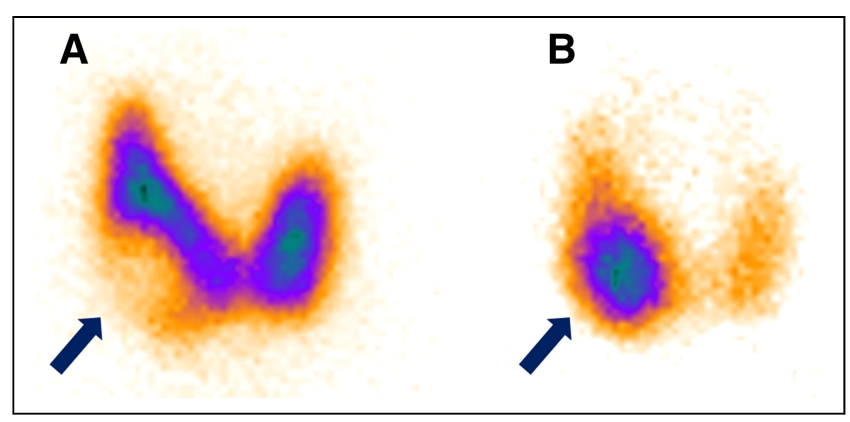

FIGURE 3. Cytologically indeterminate thyroid nodules at FNA. TS demonstrates photopenic defect on ${ }^{99 \mathrm{~m}} \mathrm{Tc}$-pertechnetate scan consistent with hypofunctioning nodule within right thyroid lobe $(A)$ with uptake and retention of ${ }^{99 \mathrm{~m}} \mathrm{TC}$-sestaMIBI (B). Histology: papillary thyroid cancer, follicular variant.

\section{A}

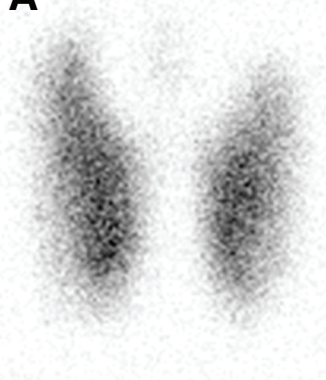

TSH $0.30 \mathrm{mUI} / \mathrm{L}$
B

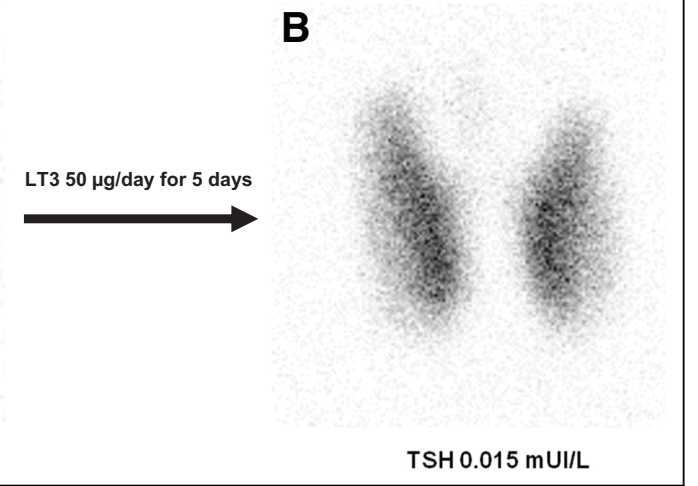

FIGURE 4. Chronically fluctuating low TSH values in woman with no biologic diagnosis for autoimmune thyroid disease (i.e., negative TRAb and TPOAb) and unremarkable MPUS (not shown). (A) Baseline TS: normal ${ }^{123}$ I thyroid uptake $(13.1 \%)$ and homogeneous tracer distribution. (B) Suppressed TS: not suppressed ${ }^{123}$ I thyroid uptake $(9.2 \%)$ and well-contrasted thyroid image after administration of liothyronine $(50 \mu \mathrm{g} / \mathrm{d})$ for $5 \mathrm{~d}$ demonstrate diffuse thyroid autonomy.
(Fig. 1). Accordingly, up to $50 \%$ of AFTNs show normal TSH values in Europe (2), leading to different recommendations on a national or regional basis $(1,41-47)$. In this case, the integration of various information (i.e., regional iodine intake, local TSH reference range, and size and MPUS features of the nodule) may better inform the decision to perform TS or not, instead of just applying fixed TSH thresholds (Fig. 2). Conversely, nonautonomous nodules are managed based on TI-RADS to select high-risk ones for FNA and cytopathology assessment $(41,42)$. Thyroid cytopathology is currently reported using the standardized Bethesda system (48), which is highly accurate in detecting or excluding malignancy in most nodules. Unfortunately, up to $25 \%$ of nodules are reported as follicular lesion of undetermined significance or atypia of undetermined significance (Bethesda III) and follicular neoplasm (Bethesda IV). As the attached risk of malignancy ranges from $10 \%$ to $50 \%$, diagnostic lobectomies/thyroidectomies are frequently performed but most indeterminate nodules are ultimately found to be benign on definitive pathology (49). Currently, both molecular testing on FNA material and molecular imaging with ${ }^{99 \mathrm{~m}} \mathrm{Tc}-\mathrm{MIBI}$ and ${ }^{18} \mathrm{~F}$-FDG should be considered before diagnostic surgery (50) (Fig. 3). Overall, molecular imaging accurately rules out whereas FNA mutational panels are more useful to rule in malignancy. ${ }^{99 \mathrm{~m}}$ Tc-MIBI- or ${ }^{18} \mathrm{~F}-\mathrm{FDG}$-negative nodules carry a risk of malignancy of only $0 \%-5 \%$ and can be safely ruled out from surgery (high NPV). Unfortunately, only 35\%-60\% of ${ }^{99 \mathrm{~m}}$ Tc-MIBI- or ${ }^{18}$ F-FDG-positive nodules are cancers (low PPV). On the other hand, BRAF mutation analysis is $100 \%$ predictive of papillary thyroid carcinoma (high PPV), but most cancers are BRAF-negative (very low NPV) (51-53). More recently, different gene expression classifier tests have standardized risk assessment for thyroid malignancy under the different Thyroid Imaging And Data Reporting Systems (TI-RADS) to mitigate the high interoperator variability $(35,36)$. Different TI-RADS systems combine, with some differences, ultrasound features such as shape, margins, echogenicity, composition, and microcalcifications in hierarchical risk categories and, overall, demonstrated a satisfactory performance (37). However, almost all information on the reliability of different TI-RADS are based on studies that included papillary thyroid carcinoma, the cancer most prevalent among all thyroid malignancies. Notably, however, the accuracy of such systems is significantly reduced in other, more aggressive, thyroid cancers such as follicular histotypes (38). Additionally, FNA is inappropriately performed in a large proportion of AFTNs, based on TI-RADS classifications (27\% to $90 \%$, depending on different TI-RADS) $(39,40)$. AFTNs have a 96\%-99\% negative predictive value (NPV) for malignancy but indeterminate cytologic features are frequently reported: accordingly FNA procedures are discouraged in such cases (41). Even if TS is essential to detect AFTNs it is neither recommended nor, in some countries, reimbursed in patients with thyroid nodules but normal TSH. Although this is reasonable in countries with adequate iodine supply, the TSH levels may remain normal in the presence of AFTNs when iodine supply is reduced as, especially early, the low synthesis rate of thyroid hormones is insufficient to suppress the TSH secretion $(42,43)$ become available, demonstrating different performance in terms of PPV and MPV (54,55). Overall, mutation mapping and gene expression analysis on FNA samples and molecular imaging can be used to refine the diagnosis in patients with indeterminate thyroid nodules. However, all methods largely depend on local cancer prevalence and pretest probabilities, and additionally high costs limit their use in many countries. Accordingly, no definitive guidelines exist, and a locally adapted multimodality stepwise approach, ideally combining one rule-in and one rule-out test, likely offers the most accurate diagnosis (50).

\section{PREDICTIVE MOLECULAR IMAGING AND THERANOSTICS}

In addition to overt thyrotoxicosis even latent forms of hyperthyroidism are responsible for an increase in cerebrovascular and cardiovascular morbidity and mortality and overall mortality (56). Recently, the risk of heart failure events was also shown to correlate with low but unsuppressed TSH values $(0.1-0.44 \mathrm{mU} / \mathrm{L})(57,58)$. In such a context, TS is the most reliable tool to differentiate true TSH-independent thyroid overactivity from nonspecific TSH fluctuations (59). In such cases, performing TS after administration of 25-60 $\mu \mathrm{g}$ T3 daily over 5-10 d allowed for the discrimination of TSH-responsive from autonomously functioning tissue (Fig. 4). Particularly, a quantified ${ }^{123} \mathrm{I}$ uptake at $24 \mathrm{~h}$ greater than $2 \%$ or technetium thyroid uptake (TcTU) at 15 min greater than $1 \%-1.8 \%$ under 
suppression are both consistent with significant thyroid autonomy (60). Alternatively, ${ }^{123}$ I uptake (mpU) can be also estimated integrating actual ${ }^{123} \mathrm{I}$ uptake and TSH levels at baseline (61). Interestingly, the TcTU at baseline or after suppression reliably predicts an evolution toward overt hyperthyroidism in patients with compensated autonomy and identifies patients at higher risk to decompensate after exogenous iodine exposure (62). In addition, TcTU provides estimates of functional volume, especially useful in planning multifocal or disseminated autonomy treatment with ${ }^{131} \mathrm{I}$ (63). Accordingly Dunkelmann et al. obtained a cure rate of $91.5 \%$ and a very low rate $(1 \%)$ of hypothyroidism in 641 patients with multifocal and disseminated autonomy integrating the dosimetric Marine1li's formula with TcTU-adapted target doses (i.e., 150 Gy for $\mathrm{TcTU}<3 \%$ to $250 \mathrm{~Gy}$ for TcTU $>12 \%$ ), respectively (64). Furthermore, functional volumes and activity quantification based on SPECT/CT measurements is now possible, allowing real-time quantification of radiation-absorbed dose in target volumes of interest based on empiric data on ${ }^{131}$ I biokinetics in tissue (65). Therefore, simplified SPECT/CT-based dosimetric protocols and the development of dedicated software should further improve patient-centered approaches to radioiodine thyroid theranostics (66). Furthermore, although current radiomic predictors are less reproducible than hoped for, integrating radiomics information with pathology, biochemical, and molecular features will make possible a refined diagnosis of thyroid nodules using artificial intelligence $(67,68)$.

\section{CONCLUSION}

For decades, nuclear medicine methods have allowed molecular/ functional characterization and tailored radioiodine therapy of different thyroid diseases. Even as accurate nonradioisotopic methods emerged over time, the selective and optimized use of TS and RAIU remains integral in differentiating the causes of hyperthyrodism and properly informs clinical and therapeutic decisions. Furthermore, among patients with thyroid nodules TS remains the only method able to detect AFTNs while aspecific tracers such as ${ }^{99 \mathrm{~m}} \mathrm{Tc}-\mathrm{MIBI}$ and ${ }^{18} \mathrm{~F}$-FDG may contribute to refining the clinical management of cytologically indeterminate cold nodules, avoiding inappropriate invasive procedures.

\section{DISCLOSURE}

No potential conflict of interest relevant to this article was reported.

\section{KEY POINTS}

QUESTION: What is the current role of molecular imaging in evaluating thyrotoxicosis and thyroid nodules?

PERTINENT FINDINGS: Thyroid scintigraphy with ${ }^{123}$ I or ${ }^{99 \mathrm{~m} T c} \mathrm{~T}$-pertechnetate allows a real-time differentiation of different forms of thyrotoxicosis, the exclusion of autonomously functioning thyroid nodules from inappropriate biopsy, and the detection of ectopic thyroid tissue. The use of either ${ }^{99 m} \mathrm{Tc}$-methoxyisobutylisonitrile (MIBI) and ${ }^{18} \mathrm{~F}-\mathrm{FDG}$ may complement the work-up of cytologically indeterminate cold nodules and contribute to reducing the need for diagnostic lobectomies/thyroidectomies.

IMPLICATIONS FOR PATIENT CARE: Thyroid molecular imaging characterizes molecular/functional aspects of different thyroid diseases, even before clinical symptoms become manifest and remains integral to properly managing such conditions.

\section{REFERENCES}

1. Giovanella L, Avram AM, Iakovou I, et al. EANM practice guideline/SNMMI procedure standard for RAIU and thyroid scintigraphy. Eur J Nucl Med Mol Imaging. 2019;46:2514-2525.

2. Treglia G, Trimboli P, Verburg FA, et al. Prevalence of normal TSH value among patients with autonomously functioning thyroid nodule. Eur J Clin Invest. 2015;45:739-744.

3. Giovanella L, Ceriani L, Treglia G. Role of isotope scan, including positron emission tomography/computed tomography, in nodular goitre. Best Pract Res Clin Endocrinol Metab. 2014;28:507-518.

4. Piccardo A, Trimboli P, Foppiani L, et al. PET/CT in thyroid nodule and differentiated thyroid cancer patients: the evidence-based state of the art. Rev Endocr Metab Disord. 2019;20:47-64.

5. Carvalho DP, Dupuy C. Thyroid hormone biosynthesis and release. Mol Cell Endocrinol. 2017;458:6-15.

6. Godbole A, Lyga S, Lohse MJ, Calebiro D. Internalized TSH receptors en route to the TGN induce local $\mathrm{G}_{\mathrm{s}}$-protein signaling and gene transcription. Nat Commun. 2017;8:443.

7. Larsen PR. Thyroid-pituitary interaction: feedback regulation of thyrotropin secretion by thyroid hormones. NEngl J Med. 1982;306:23-32.

8. Hoermann R, Midgley JE, Larisch R, Dietrich JW. Homeostatic control of the thyroid-pituitary axis: perspectives for diagnosis and treatment. Front Endocrinol (Lausanne). 2015;6:177.

9. Thienpont LM, Uytfanghe KV, Poppe K, Velkeniers B. Determination of free thyroid hormones. Best Pract Res Clin Endocrinol Metab. 2013;27:689-700.

10. Kimura T, Van Keymeulen A, Golstein J, Fusco A, Dumont JE, Roger PP. Regulation of thyroid cell proliferation by tsh and other factors: a critical evaluation of in vitro models. Endocr Rev. 2001;22:631-656.

11. Shapiro B, Britton K, Fountos A, et al. A multiobserver comparison of $99 \mathrm{mTcO} 4$ and ${ }^{123}$ I thyroid imaging. Eur J Nucl Med. 1981;6:135-138.

12. Clerc J. Exploration isotopique de la thyroïde. 2nd ed. In: Traité d'Endocrinologie. Chanson PH, Young J, eds. Médecine Sciences, Flammarion;2019; 127-138.

13. Strauss HW. MIBI and mitochondria. J Am Coll Cardiol. 2013;61:2018-2019.

14. Rager O, Radojewski P, Dumont RA, et al. Radioisotope imaging for discriminating benign from malignant cytologically indeterminate thyroid nodules. Gland Surg. 2019;8(suppl 2):S118-S125.

15. De Leo S, Lee SY, Braverman E. Hyperthyroidism. Lancet. 2016;388:906-918.

16. Biondi B, Palmieri EA, Klain M, Schlumberger M, Filetti S, Lombardi G. Subclinical hyperthyroidism: clinical features and treatment options. Eur $J$ Endocrinol. 2005; 152:1-9.

17. Faix JD. Principles and pitfalls of free hormone measurements. Best Pract Res Clin Endocrinol Metab. 2013;27:631-645.

18. Plebani M, Giovanella L. Reflex TSH strategy: the good, the bad and the ugly. Clin Chem Lab Med. 2019;58:1-2.

19. Meller J, Jauho A, Hufner M, Gratz S, Becker W. Disseminated thyroid autonomy or Graves' disease: reevaluation by a second generation TSH receptor antibody assay. Thyroid. 2000;10:1073-1079.

20. Laulund AS, Nybo M, Brix TH, Abrahamsen B, Jørgensen HL, Hegedüs L. Duration of thyroid dysfunction correlates with all-cause mortality. the OPENTHYRO Register Cohort. PLoS One. 2014;9:e110437.

21. Vanderpump MP. The epidemiology of thyroid disease. Br Med Bull. 2011;99:39-51.

22. Kravets I. Hyperthyroidism: diagnosis and treatment. Am Fam Physician. 2016;93:363-370.

23. Ross DS, Burch HB, Cooper DS, et al. 2016 American Thyroid Association guidelines for diagnosis and management of hyperthyroidism and other causes of thyrotoxicosis. Thyroid. 2016;26:1343-1421.

24. Tozzoli R, D'Aurizio F, Villalta D, et al. Evaluation of the first fully automated immunoassay method for the measurement of stimulating TSH receptor autoantibodies in Graves' disease. Clin Chem Lab Med. 2017;55:58-64.

25. Sahlmann CO, Siefker U, Lehmann K, et al. Quantitative thyroid scintigraphy for the differentiation of Graves' disease and hyperthyroid autoimmune thyroiditis. Nuklearmedizin. 2004;43:124-128.

26. Giovanella L, Ceriani L, Ghelfo A. Second-generation thyrotropin receptor antibodies assay and quantitative thyroid scintigraphy in autoimmune hyperthyroidism. Horm Metab Res. 2008;40:484-486.

27. Erdoğan MF, Anil C, Cesur M, et al. Color flow doppler sonography for the etiologic diagnosis of hyperthyroidism. Thyroid. 2007;17:223-228.

28. Scappaticcio L, Trimboli P, Keller F, Imperiali M, Piccardo A, Giovanella L. Diagnostic testing for Graves' or non-Graves' hyperthyroidism: a comparison of two thyrotropin receptor antibody immunoassays with thyroid scintigraphy and ultrasonography. Clin Endocrinol (Oxf). 2020;92:169-178.

29. Smith TJ, Hegedus L. Graves' disease. N Engl J Med. 2016;375:1552-1565.

30. Mizukami Y, Michigishi T, Kawato M, et al. Chronic thyroiditis: thyroid function and histologic correlations in 601 cases. Hum Pathol. 1992;23:980-988. 
31. Clerc J. Imagerie Isotopique des hyperthyroïdies infracliniques. Syndromes d'autonomisation. In Imagerie de la Thyrö̈de et des Parathyrö̈des. Tramalloni J, ed. Médecine Sciencs Publications; 2012:177-187.

32. Piga M, Cocco MC, Serra A, Boi F, Loy M, Mariotti S. The usefulness of ${ }^{99 m}$ TcsestaMIBI thyroid scan in the differential diagnosis and management of amiodarone-induced thyrotoxicosis. Eur J Endocrinol. 2008;159:423-429.

33. Pattison DA, Westcott J, Lichtenstein M, et al. Quantitative assessment of thyroidto-background ratio improves the interobserver reliability of technetium-99m sestamibi thyroid scintigraphy for investigation of amiodarone-induced thyrotoxicosis. Nucl Med Commun. 2015;36:356-362.

34. Hegedüs L. Clinical practice. The thyroid nodule. $N$ Engl $J$ Med. 2004;351:1764-1771.

35. Choi SH, Kim EK, Kim SJ, Kwak JY. Thyroid ultrasonography: pitfalls and techniques. Korean J Radiol. 2014;15:267-276.

36. Horvath E, Majlis S, Rossi R, et al. An ultrasonogram reporting system for thyroid nodules stratifying cancer risk for clinical management. J Clin Endocrinol Metab. 2009;94:1748-1751.

37. Castellana M, Grani G, Radzina M, et al. Performance of EU-TIRADS in malignancy risk stratification of thyroid nodules: a meta-analysis. Eur $J$ Endocrinol. 2020;183:255-264.

38. Castellana M, Piccardo A, Virili C, et al. Can ultrasound systems for risk stratification of thyroid nodules identify follicular carcinoma? Cancer Cytopathol. 2020;128:250-259.

39. Castellana M, Virili C, Paone G, et al. Ultrasound systems for risk stratification of thyroid nodules prompt inappropriate biopsy in autonomously functioning thyroid nodules. Clin Endocrinol (Oxf). 2020;93:67-75.

40. Schenke S, Seifert P, Zimny M, Winkens T, Binse I, Goerges R. Risk stratification of thyroid nodules using Thyroid Imaging Reporting And Data System (TIRADS): the omission of thyroid scintigraphy increases the rate of falsely suspected lesions. J Nucl Med. 2019;60:342-347.

41. Haugen BR, Alexander EK, Bible KC, et al. 2015 American Thyroid Association management guidelines for adult patients with thyroid nodules and differentiated thyroid cancer: the American Thyroid Association guidelines task force on thyroid nodules and differentiated thyroid cancer. Thyroid. 2016;26:1-133.

42. Chami R, Moreno-Reyes R, Corvilain B. TSH measurement is not an appropriate screening test for autonomous functioning thyroid nodules: a retrospective study of 368 patients. Eur J Endocrinol. 2014;170:593-599.

43. Giovanella L, D'Aurizio F, Campenni' A, et al. Searching for the most effective thyrotropin (TSH) threshold to rule-out autonomously functioning thyroid nodules in iodine deficient regions. Endocrine. 2016;54:757-761.

44. Gharib H, Papini E, Garber JR, et al. American Association of Clinical Endocrinologists, American College of Endocrinology, and Associazione Medici Endocrinologi medical guidelines for clinical practice for the diagnosis and management of thyroid nodules-2016 update. Endocr Pract. 2016;22:622-639.

45. Verburg FA, Aktolun C, Chiti A, et al. Why the European Association of Nuclear Medicine has declined to endorse the 2015 American Thyroid Association management guidelines for adult patients with thyroid nodules and differentiated thyroid cancer. Eur J Nucl Med Mol Imaging. 2016;43:1001-1005.

46. Dietlein M, Dressler J, Eschner W, et al. Procedure guideline for thyroid scintigraphy (version 3). Nuklearmedizin. 2007;46:203-205.

47. Musholt TJ, Clerici T, Dralle H, et al. German Association of Endocrine Surgeons practice guidelines for the surgical treatment of benign thyroid disease. Langenbecks Arch Surg. 2011;396:639-649.

48. Cibas ES, Ali SZ. The 2017 Bethesda system for reporting thyroid cytopathology. Thyroid. 2017;27:1341-1346.
49. Ross D. Evaluation and management of thyroid nodules with indeterminate cytology. Up to Date 2018. https://www.uptodate.com/contents/evaluation-and-management-of-thyroid-nodules-with-indeterminate-cytology. Accessed on June 12, 2020.

50. de Koster EJ, de Geus-Oei LF, Dekkers OM, et al. Diagnostic utility of molecular and imaging biomarkers in cytological indeterminate thyroid nodules. Endocr Rev. 2018;39:154-191.

51. Giovanella L, Campenni A, Treglia G, et al. Molecular imaging with ${ }^{99 \mathrm{~m}} \mathrm{Tc}-\mathrm{MIBI}$ and molecular testing for mutations in differentiating benign from malignant follicular neoplasm: a prospective comparison. Eur J Nucl Med Mol Imaging. 2016;43:1018-1026.

52. Piccardo A, Puntoni M, Treglia G, et al. Thyroid nodules with indeterminate cytology: prospective comparison between ${ }^{18} \mathrm{~F}$-FDG-PET/CT, multiparametric neck ultrasonography, ${ }^{99 \mathrm{~m}} \mathrm{Tc}-\mathrm{MIBI}$ scintigraphy and histology. Eur J Endocrinol. 2016;174:693-703.

53. Trimboli P, Treglia G, Condorelli E, et al. BRAF-mutated carcinomas among thyroid nodules with prior indeterminate FNA report: a systematic review and metaanalysis. Clin Endocrinol (Oxf). 2016;84:315-320.

54. Alexander EK, Kennedy GC, Baloch ZW, et al. Preoperative diagnosis of benign thyroid nodules with indeterminate cytology. N Engl J Med. 2012;367:705-715.

55. Nishino M, Nikiforova M. Update on molecular testig for cytologically indeterminate thyroid nodules. Arch Pathol Lab Med. 2018;142:446-457.

56. Lillevang-Johansen M, Abrahamsen B, Jørgensen HL, Brix TH, Hegedüs L. Duration of hyperthyroidism and lack of sufficient treatment are associated with increased cardiovascular risk. Thyroid. 2019;29:332-340.

57. Haentjens P, Van Meerhaeghe A, Poppe K, Velkeniers B. Subclinical thyroid dysfunction and mortality: an estimate of relative and absolute excess all-cause mortality based on time-to-event data from cohort studies. Eur J Endocrinol. 2008;159:329-341.

58. Gencer B, Collet TH, Virgini V, et al. Subclinical thyroid dysfunction and the risk of heart failure events: an individual participant data analysis from 6 prospective cohorts. Circulation. 2012;126:1040-1049.

59. Wang D, Cheng X, Yu S, et al. Data mining: seasonal and temperature fluctuations in thyroid-stimulating hormone. Clin Biochem. 2018;60:59-63.

60. Meller J, Becker W. The continuing importance of thyroid scintigraphy in the era of high-resolution ultrasound. Eur J Nucl Med Mol Imaging. 2002;29(suppl 2):S425-S438.

61. Clerc J. Quantitated thyroid scan $\left({ }^{123} \mathrm{I}\right)$ of the thyroid nodule: a new molecular imaging. J Radiol. 2009;90:371-391.

62. Fricke E, Fricke H, Esdorn E, et al. Scintigraphy for risk stratification of iodineinduced thyrotoxicosis in patients receiving contrast agents for coronary angiography: a prospective study of patients with low thyrotropin. J Clin Endocrinol Metab. 2004;89:6092-6096.

63. Reinhardt MJ, Joe A, von Mallek D, et al. Dose selection for radioiodine therapy of borderline hyperthyroid patients with multifocal and disseminated autonomy on the basis of ${ }^{99 \mathrm{~m}} \mathrm{Tc}$-pertechnetate thyroid uptake. Eur J Nucl Med Mol Imaging. 2002;29:480-485.

64. Dunkelmann S, Endlicher D, Prillwitz F, et al. Results of TcTU-optimized radioiodine therapy in multifocal and disseminated autonomy. Nuklearmedizin. 1999;38:131-139.

65. Hänscheid H, Lassmann M. Will SPECT/CT cameras soon be able to display absorbed doses? Dosimetry from single-activity-concentration measurements. J Nucl Med. 2020;61:1028-1029.

66. Fujita N, Koshiba Y, Abe S, Kato K. Investigation of post-therapeutic image-based thyroid dosimetry using quantitative SPECT/CT, iodine biokinetics, and the MIRD's voxel S volume in Graves' Disease. EJNMMI Phys. 2020;7:6.

67. Ceriani L, Milan L, Virili C, et al. Radiomic analysis of $\left[{ }^{18} \mathrm{FDG}\right]$ fluorodeoxyglucose-avid thyroid incidentalomas improves risk stratification and selection for clinical assessment. Thyroid. 2021;31:88-95.

68. Zwanenburg A. Radiomics in nuclear medicine: robustness, reproducibility, standardization, and how to avoid data analysis traps and replication crisis. Eur J Nucl Med Mol Imaging. 2019;46:2638-2655. 